\title{
Unidirectional splitting and uniting of rays in the cambium of Platanus accompanying the formation of interlocked grain in wood
}

\section{J. KRAWCZYSZYN}

Department of Plant Anatomy and Cytology, Institute of Botany and Biochemistry Wroclaw University, Wrocław, Kanonia 6/8.

(Received: May 9, 1970)

Abstract:

Developmental changes in the cambium producing interlocked grain wood of Platanus, were determined by an analysis of successive late xylem layers (TLX) at the borders of the annual rings. Intensive splitting and uniting of rays were observed. These occured by intrusion of fusiform cells into the rays and by loss of the fusiform initials which formed the strands separating the rays, respectively. Uniting of rays was unidirectional within the large areas of cambium (domain), so was the splitting, too. There were domains of $\mathrm{Z}$ and $\mathrm{S}$-type. Orientation of splitting and uniting of rays at a particular locality of the cambium was reversed at irregular time intervals. It appears that the reason for these reversals was slow movement of domain pattern. The occurrence of alternating $\mathrm{Z}$ and $\mathrm{S}$ domains brought about the alternation of the grain inclination from right to left and back again in the interlocked-grained wood.

\section{INTRODUCTION}

The genus Platanus is characterized by initerlocked-grained wood. The grain in this type of wood is spiral, that is the wood elements are laid in an inclined direction around the circumference, but reversal of spirals takes place (Brown et al. 1949; Lim a y e, 1954). In other words, the inclination of the grain changes here from right or left to the opposite direction in successive groups of annual rings many times in the course of the tree's life. These changes seem to be due to changes in the cambium, because the arrangement of cells in the xylem is generally determined by that in the cambium. Therefore, intensive developmental changes are to be expected in the cambium of Platanus.

The history of the changes in the cambium is recorded in the pattern of the xylem cells, therefore, by investigating the xylem, this history may be reconstructed. It results from investigations performed to date that the cambium is capable of highly dynamic transformation and of rapid readjustments of fusiform and ray initials. If we define cambium as ,a layer which constantly reproduces itself in successively widening con- 
centric sheets" (H a r r is, 1969), it should be added that it is capable of reproducing itself in a changed form. The high sensitivity of this tissue to physical and chemical factors and its plasticity, owing to which its cells can rapidly adjust themselves to the changed conditions, for instance by placing themselves askew or even transversely to the vertical, is stressed by $\mathrm{N}$ e ef (1914).

Vascular cambium consists of two morphologically different types of initials. These types can interchange: the fusiform initials can, by transverse or lateral division, give rise to ray initials, and the latter can elongate forming fusiform initials. The transition of fusiform to ray initials and vice versa has its basis in the similarity of their structure (Srivastava and O'Brien 1966). The cambial cells divide in two ways - periclinally, i.e. parallelly to the surface of the cambium cylinder, and anticlinally, i.e. normally to it. The former divisions serve for secondary xylem and phloem formation, and directly influence the amount of these tissues in trees, the latter increase the number of cambium cells. In nonstoried cambium the anticlinal divisions of fusiform initials are pseudotransverse either of $\mathrm{Z}$ or $\mathrm{S}$ type (B a n n a n, 1950, 1964, 1966; Hejnowicz, 1964, 1968). The orientation of the anticlinal divisions is the same within a smaller of greater area of the cambium called a domain (B an na n, 1966; H e jnowicz, 1964). In such an area, the orientation of overlap of intrusively growing cell tips is also the same as the orientation of the divisions ( $\mathrm{B}$ a $\mathrm{n} \mathrm{n}$ a $\mathrm{n}, 1966 ; \mathrm{He} \mathrm{j} n \mathrm{ow} \mathrm{i} \mathrm{z}, 1968$ ). The anticlinal divisions and the following intrusive growth increase the surface of the nonstoried cambium, but these processes are much more active than it would be necessary for the growth of the cylinder as it advances away from the pith, therefore part of the fusiform initials from the cambium are lost.

The above described changes in the fusiform initials are associated with changes in the rays - splitting and uniting. Splitting of the rays may be due to the change of the ray initials to fusiform ones or to intrusion into the ray of fusiform initials ( $\mathrm{Ch}$ a t t a w a y, 1933; B a r ghoorn, 1940, 1941; C h e a d le and $\mathrm{Esa} u, 1964)$. Uniting of two rays may occur by elongation of the marginal initials of superposed rays (B a r g h o or n, 1940, 1941), by loss of fusiform initials or by their transformation to ray initials ( $\mathrm{E}$ ver t, 1961; $\mathrm{C}$ h e a d le and $\mathrm{Es}$ a u, 1964).

As alredy mentioned, there exist in the cambium the domains characterized by unidirectional inclination of anticlinal partitions and uniformly oriented intrusive growth. Also the direction of ray splitting is the same within a domain ( $\mathrm{Hejnowicz}$ and $\mathrm{Krawczyszyn}$, 1969). Domains of $\mathrm{Z}$ and $\mathrm{S}$ type can be distinguished. The type of domain at a particular locality of the cambium changes in the ontogenesis of trees.

Pseudotransverse anticlinal division, intrusive growth, loss of fusi- 
form initials and ray splitting affect directly the cellular structure of the cambium, they may, therefore, be considered as the basic factors of anatomical development of the cambium. It is believed that the uniform orientation of these factors may cause deviation of cambial cells from the vertical, resulting in the formation of inclination grain. Attention is called to the role played here by pseudotransverse anticlinal divisions (N e w m a n n, 1955; H e j n o w i c z, 1961) and by intrusive growth (H a rris, 1969). Hejnowicz (1968) found that unidirectional anticlinal division, oriented intrusive growth and loss of some of the cambial initials lie at the base of changes of the cell angle. The change in the grain inclination angle is associated with rotation of the rays around their centres ( $\mathrm{J}$ ones, 1963; Hejnowicz, 1968), a marked rearrangement of the fusiform initials in respect to each other ( $J$ o n e s, 1963; H a r r is, 1969) and a shift of the tips of the fusiform initials from the left side of the rays to the right with inclination of the grain from left to right ( $\mathrm{J}$ o n e s, 1963).

The question arises how does the cell pattern change in the cambium producing interlocked - grained wood, especially what developmental processes of the cambium lie at the base of the reversal of spirals in this type of grain. This problem is the more interesting, since our up-to-date knowledge of the developmental processes in the cambium, responsible for the formation of spiral grain is solely based on investigation of the primitive wood of coniferous trees. It seems possible to answer this question owing to the earlier finding ( $\mathrm{H}$ e j n o w i c z and $\mathrm{Kr}$ a w c z y s z y n, 1969) that in broadleaved trees the pattern of the cambial initials is preserved in the late xylem layer at the borders of the annual rings.

\section{MATERIALS AND METHOD}

The object investigated was a fragment of Platanus occidentalis L. wood from North America and cambium from Platanus acerifolia Willd. The dimensions of the wood fragment were ca. $31 \times 13 \times 6 \mathrm{~cm}$, and it comprised 48 peripheral annual rings. Judging by the small curvatures of the annual ring borders, and the almost parallel arrangement of the xylem rays, it may be supposed that this piece of wood was derived from a mature tree specimen, nothing more being known about it. From this piece wood blocks with tangential dimensions $11 \times 14 \mathrm{~mm}$ were taken, along the wood rays. They were boiled in water and then soaked in a 60 percent alcohol-glycerine mixture (ca. 3:1). The blocks were cut into tangential sections $35 \mu$ thick by means of a sliding microtome. Sections from the borders betwen annual rings were chiefly chosen for examination, comprising the terminal xylem layer (TLX). The samples were attached to the slides with Haupt's adhesive, dried and deareated by immers- 
ion in boiling absolute alcohol, transferred to xylene and embedded in Canada balsam. In view of the large number of sections examined, very useful proved large glass slides and coverslips $(10 \times 7 \mathrm{~cm})$.

The sections were photographed on Brom-D paper with a Zeiss Documator apparatus enlarging 15 times. Photographs of the successive TLX layers were studied.

Cambium samples with adjacent phloem and xylem layers were taken on July 14, 1969 from two upper branches of a mature specimen of Platanus acerifolia growing in the Botanical Garden of the Wrocław University. In the samples the nonconducting phloem tissue was carefully removed, and the cambium with young phloem and xylem was fixed in $\mathrm{Cr}-\mathrm{A}-\mathrm{F}(0.4-3-10)$, and after passing through alcohol and xylene, embedded in paraffin. The material in paraffin was cut into tangential sections $20 \mu$ thick and stained with tannin (cell walls) and hematein (cell plates and mitotic figures). The surface of the cambium samples were flattened by warming the paraffin-embedded cambium to ca. $37^{\circ} \mathrm{C}$ and then pressing down with a slide and cooling.

\section{RESULTS}

Figure $1 \mathrm{~A}$ shows a fragment of radial surface of the investigated block of wood. The rays were cut longitudinally (in respect to their own axes) only in the middle strip of the surface while in the peripherical strips they were cut obliquely because these strips correspond to the portion of xylem with the grain slanted from the vertical. Fig. 1B shows a series of terminal xylem layers (TLX). The direction of grain inclination changes twice between rings 23 and 25, and 33 and 38. During formation of rings $23-33$ a change occurred in the inclination of the grain from the position $\mathrm{S}$ to $\mathrm{Z}$. The next cycle of changes from $\mathrm{Z}$ to $\mathrm{S}$ lasted, however, much longer - over the period of formation of the rings 33-45. It may be concluded therefrom that the rate of reversals of the grain pattern may vary.

The studies of successive TLX-layers demonstrated that the rays of Platanus undergo intensive changes of splitting and uniting. These changes sometimes make the finding of rays of the same origin difficult on the successive photographs of TLX. The splitting of rays is connected with the formation of new strands in the longitudinal system, inclined to the right $-\mathrm{Z}$ or to the left $-\mathrm{S}$. The uniting of rays consists in the disappearance of the strand of the longitudinal system primarily separating them, thus, in the loss of the strands inclined to the left or right. This is illustrated in Fig. 2 in which fragments of tangential sections from TLX are shown from four successive annual rings. The photographs in this figure correspond to four successive development stages of the cambium. As seen, 

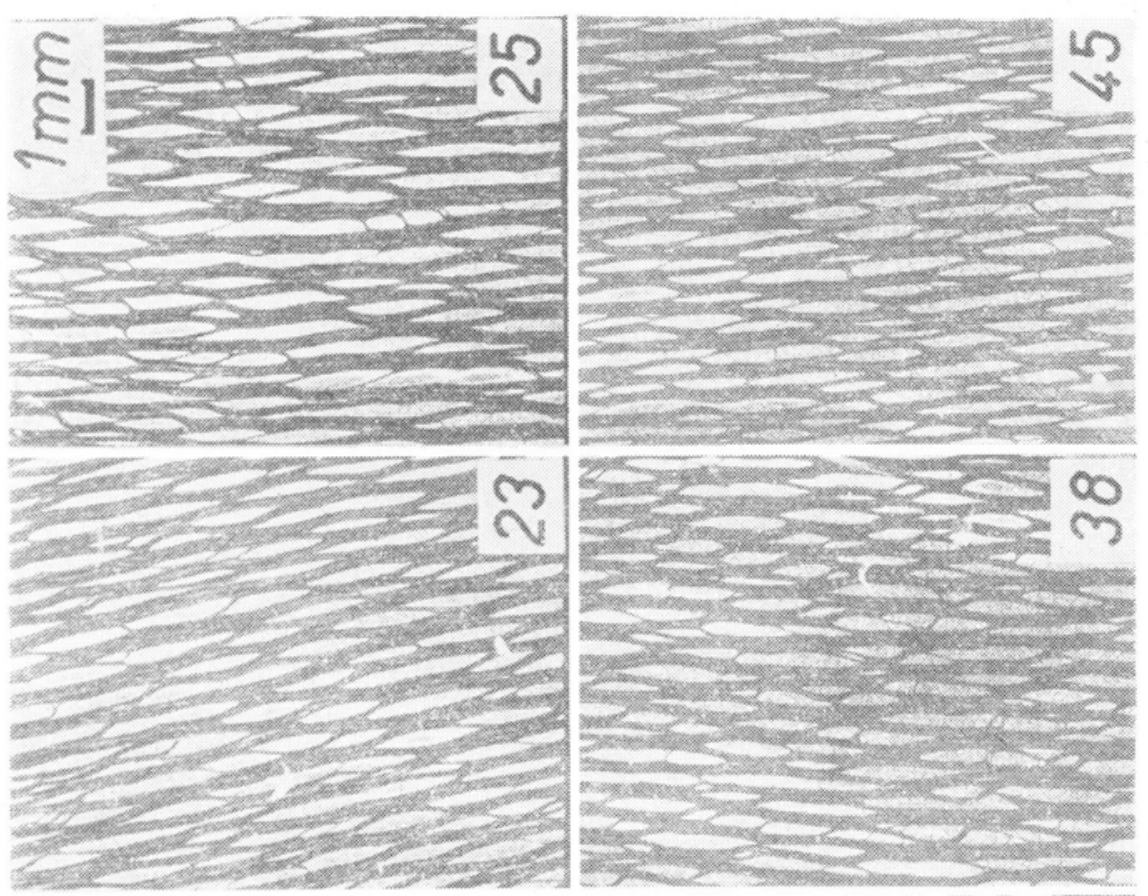

on 0

. สี

ฮ్ర

它

동 o

$\because$

$30 \infty$

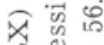

今

氙总

in का

०ू

ब完

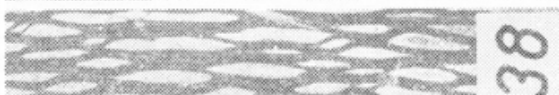

땅 오

(1) को

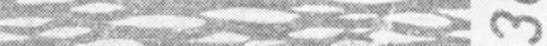

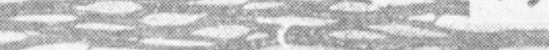

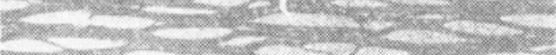

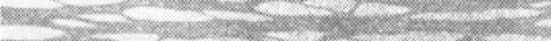

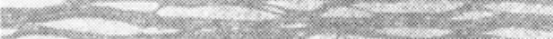

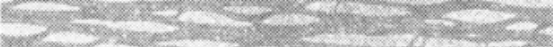

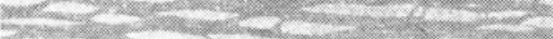

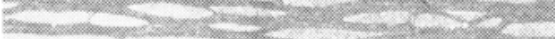

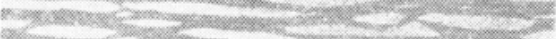

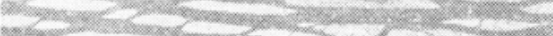

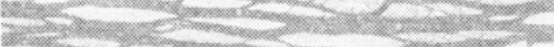

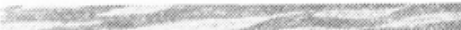
20.

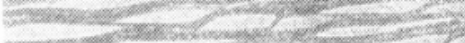

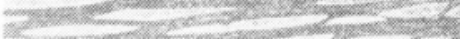

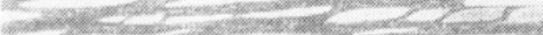

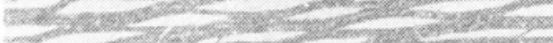
(x) S. 20in

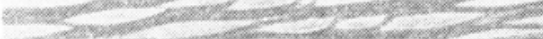

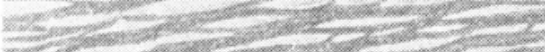

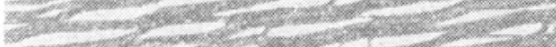
200.

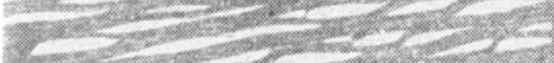
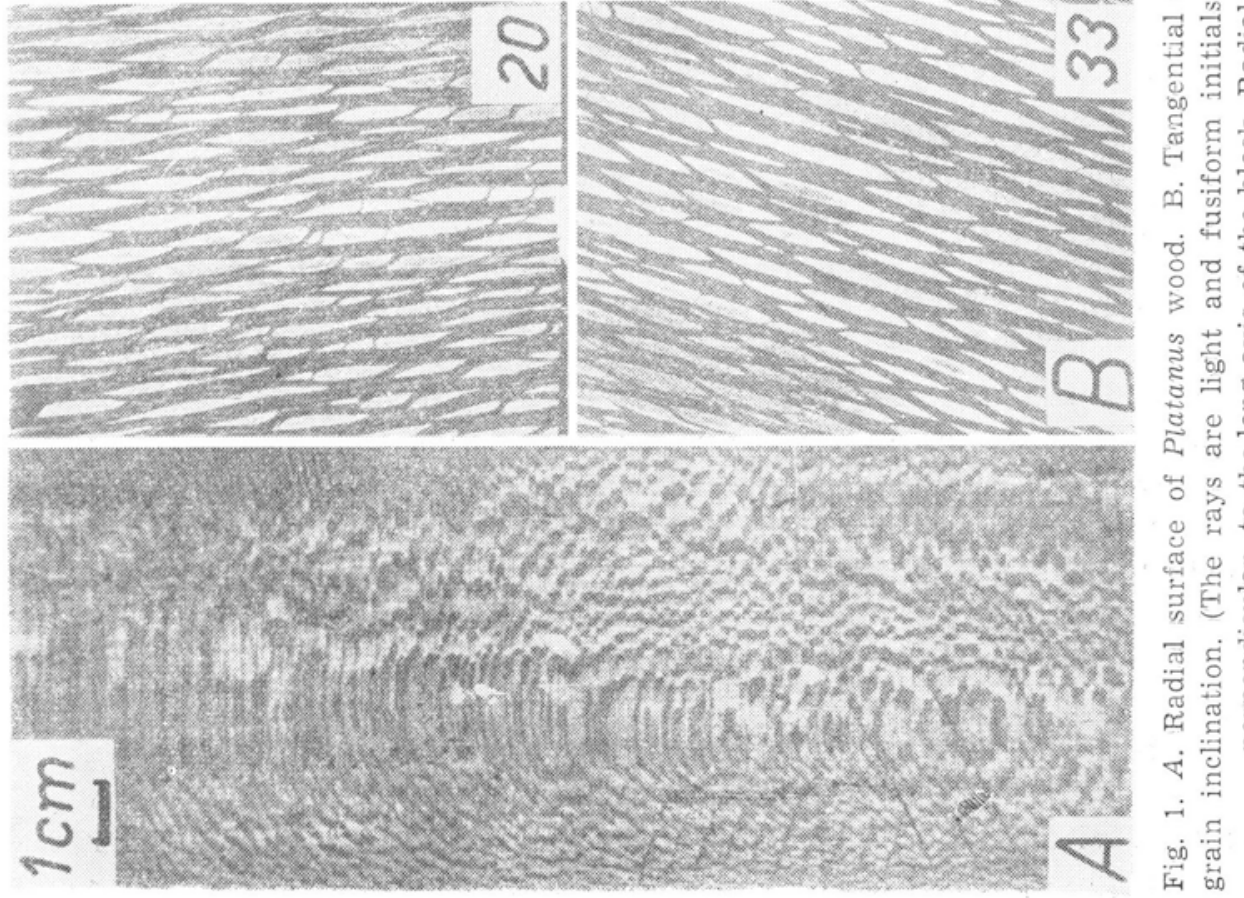

$x$ is

$-8 x$

品是

है

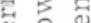

오 잉

다

है :

4.

G

要

ष

$\Rightarrow \stackrel{\text { th }}{=}$

常学

드 ๙

की

है 담

स

․

(2)

نं

당

तี

क 4 茨

क

๘ $=1$

잉

단

4 的赶

\%

ब

엉

点

寻 टं

ซ్

记

. 禁 

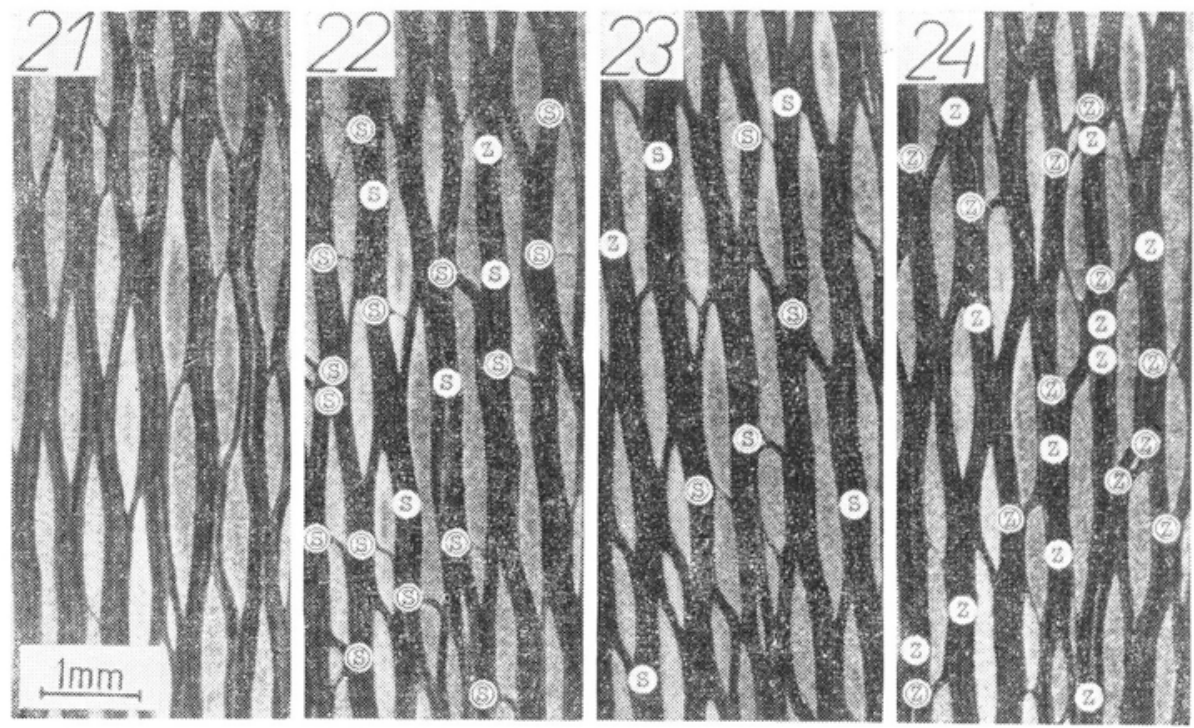

Fig. 2. Terminal xylem layers from successive annual rings. (Rays light). Splitting and uniting of rays can be recognized by comparing the given layer with the preceding one. The direction of splitting and uniting of rays is uniform on the surface considered. Distance between TLX is $2.1,3.0$, and $2.9 \mathrm{~mm}$, successively

the direction of ray splitting is the same in each ring, i.e. of type $\mathrm{S}$ - in rings 22 and 23, and of 'type $Z$ - in ring 24. The splits of type $Z$ (to the right) are associated here with the uniting of rays separated by diagonal strands inclined to the left and vice versa. According to this, the uniting of rays separated by strands inclined to the left was denoted as being of type $\mathrm{Z}$, and that of rays separated by strands inclined to the right - of type $\mathrm{S}$. The xylem rays of the sycamore are multiseriate and lie relatively close to one another. Most frequently they have the shape of biconvex lenses, owing to which the superposed rays are separated by diagonal strands inclined to the right or left. On photographs of the TLX (Fig. 2) the rays occupy almost one half of the surface area of the section, although they constitute only 19.2 percent of the wood volume (cf. B r o w n et al., 1949). This differences is due to their narrowing during differentiation of xylem elements. Only in the period of late xylem (TLX) formation does the width of the rays remain the same as it was in the cambium.

Examination of successive TLX revealed the splitting and uniting of rays, however, the reconstruction in detail of the changes in the fusiform initials was impossible. Repeated trials of reconstruction of the changes in the fusiform initials, mainly of the orientation of anticlinal partitions did not give positive results, because the origin of numerous cells could not be established. In the cambium very intensive changes must have occurred in the pattern of the cambium, due probably to intrusive elongation and loss of fusiform initials. Therefore, the short fibres visible in 
one TLX layer (representing fusiform initials) cannot always be identified in the next one.

There are two ways of ray dissection in dicotyledons: by expansion of ray initials to the fusiform size, or by penetration of rays by neighbouring fusiform initials (Ch a t t a w a y, 1933; B a r g hoor n, 1940, 1941). In the sycamore splitting occurs by penetration of rays by neighbouring fusiform initials. However, on the basis of observation of a single section it might seem that splitting of the rays occurs by elongation of the

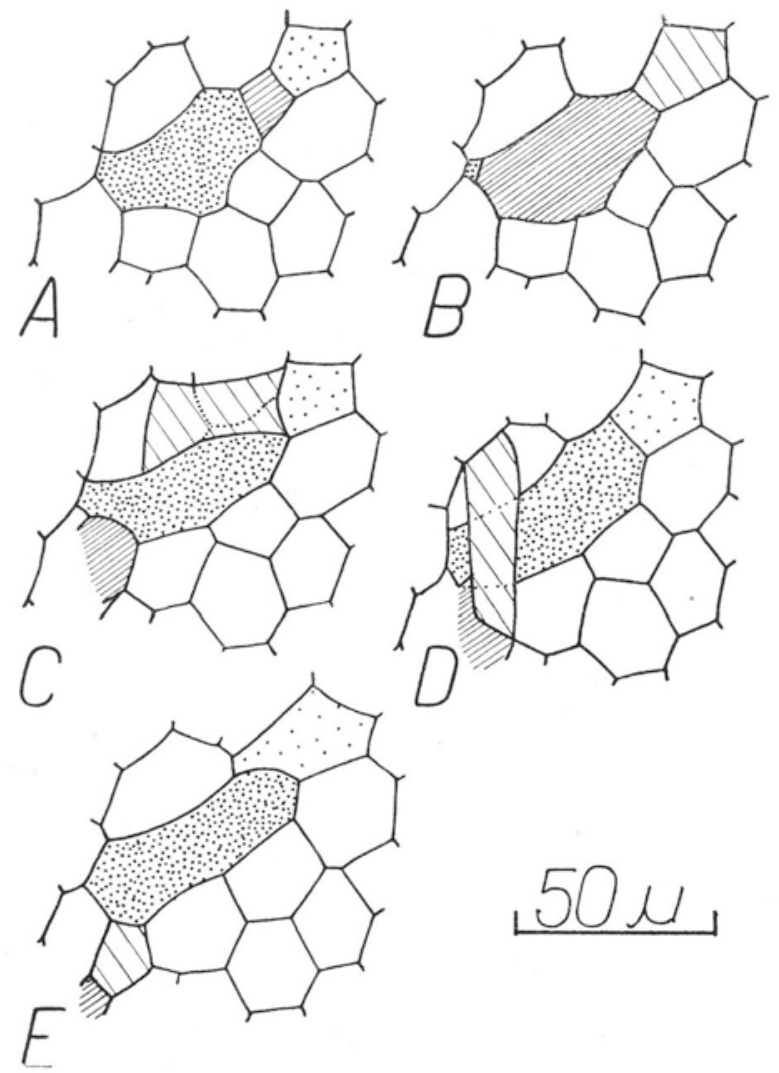

Fig. 3. Tangential section from site at which splitting of the ray starts.

By superposition of the successive figures $A-E$ the shaded area may be recognized as fragments of fusiform initials intruding into the ray. Dotted cell areas represent ray initials in the radial files, the continuity of which was interrupted owing to intrusion of fusiform cells. Distance between $A$ and $E$ is ca. $80 \mu$

ray initials. This impression, however is misleading. It results from the fact that the ends or large fragments of the fusiform cells in the ray, intruding from outside the ray do not lie in the tangential plane of the cut section, and cut askew look like coalesced ray cells. The true nature of these cells may only be recognised after very careful analysis of the special arrangement of the ray cells. For this purpose photographs were 
used of the successive wood sections, taking into account the microscopic pictures of $2-4$ successive optic levels of the $40 \mu$ sections. Five different microscopic pictures obtained in this way from three successive wood sections at the initial stage of ray splitting are shown in Fig. 3. In order to find out how the ray is dissected in the object of our study, the successive drawings $A-E$ should be superposed. It will then appear that the hatched cells exhibit no continuity with the files of ray cells. What is more, the hatched cells join one another on the successive pictures to form fusiform cells. Hence the conclusion that the hatched areas are fragments of fusiform cells intruding into the ray. At the same time the ray cells marked on the figure by dots are partly or completely invisible at some optical levels of the section, and their place is occupied by fragments of fusiform cells growing from outside into the ray. This means that the gaps in the files of ray initials are due to the penetration of fusiform cells by intrusive growth. The disappearance and appearance of ray initials on the successive tangential sections gives reason to believe that the intrusion of fusiform cells into the ray starts in the zone of xylem mother cells and that this process does not at first interfere with the division of the ray initials remaining in the cambium. Their daughter cells, however, have a limited possibility of elongation in radial direction, this being prevented by the pressure of fusiform cells growing into the ray, therefore they elongate somewhat in tangential direction in accordance with the direction of intrusion of the fusiform cells. Later as more and more of these cells intrude into the ray, the ray initials are pushed away completely from the cambium to the phloem side, and their place is occupied by fusiform cells. In the case of splitting of $Z$ type, the tips of the fusiform cells growing into the ray are inclined to the right, and in S-type splitting to the left.

In the sycamore overlying rays unite as a rule. Part of the fusiform initials in the strand separating two rays is eliminated, and the remaining ones transform to ray initials. The first symptom of an uniting is a gradual narrowing of the separating strand of the longitudinal conducting system, and a gradual approximation of the rays. Precise observation of the changes in the diagonal strand cells in this period is unfortunately not possible, because the vessels and fibres occurring here practically rule out the identification of cells in respect to their origin. It may be supposed, however, on the basis of earlier data (cf. C h e a d l e and $\mathrm{E} \mathrm{s} \mathrm{a} \mathrm{u}$, 1964; Evert, 1961) that the narrowing of the strands and the approximation of the rays due to it are caused by withdrawal and loss of fusiform cells. The end phase in the uniting of two xylem rays in the sycamore is shown in Fig. 4. It is seen that the fusiform cells in the strand separating two rays become much shorter $(A-C)$ and then divide, giving rise to isodiametric cells $(C-F)$. Part of the cells formed in this way is eliminated, and those which survive are added to the existing cells of the 

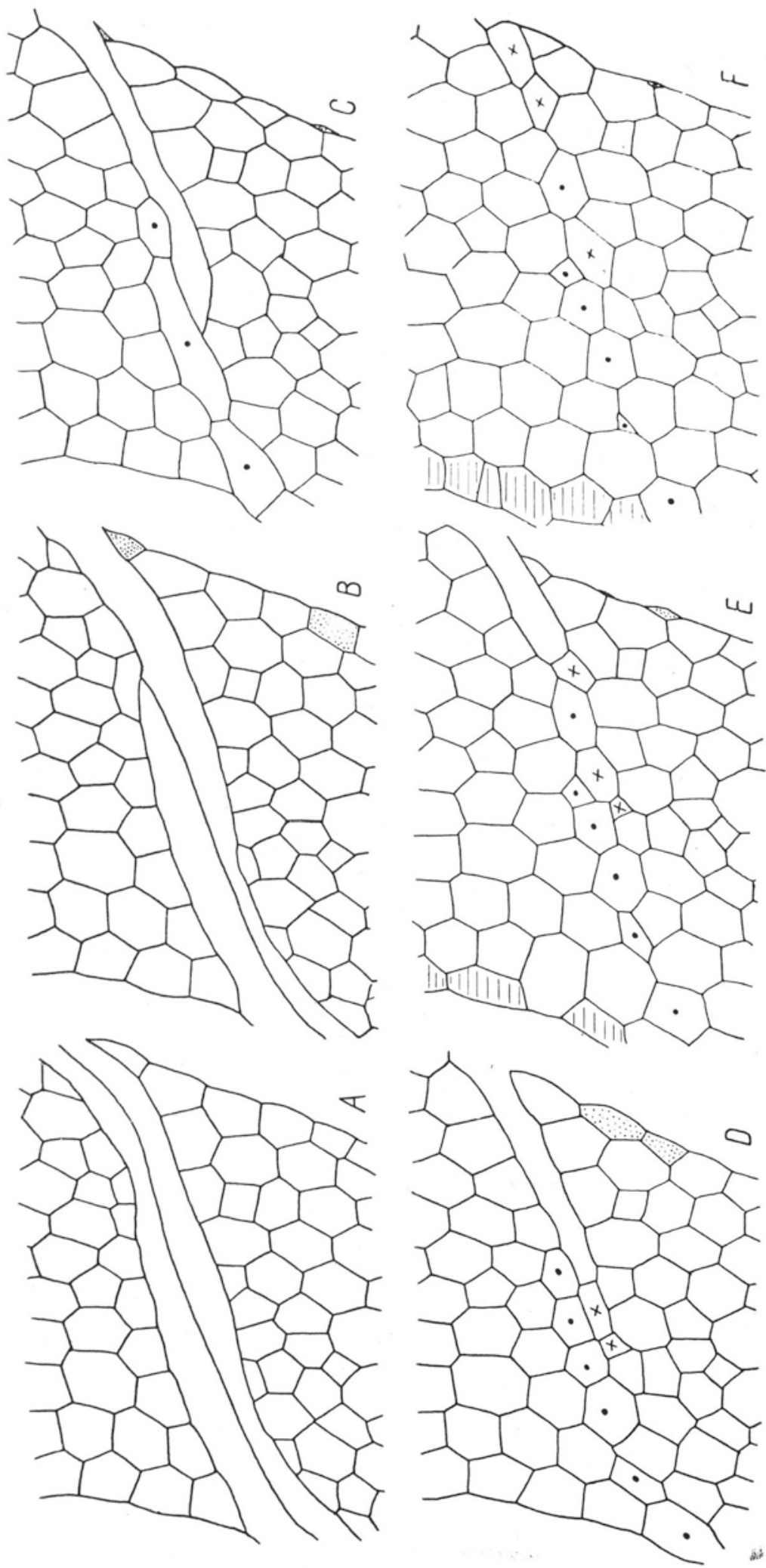

.

도윯ㅇ

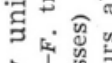
तิ

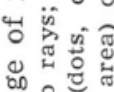

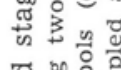

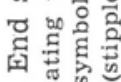
+ं क्ष ข

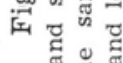

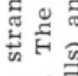
프

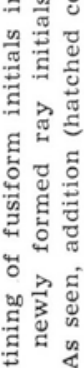



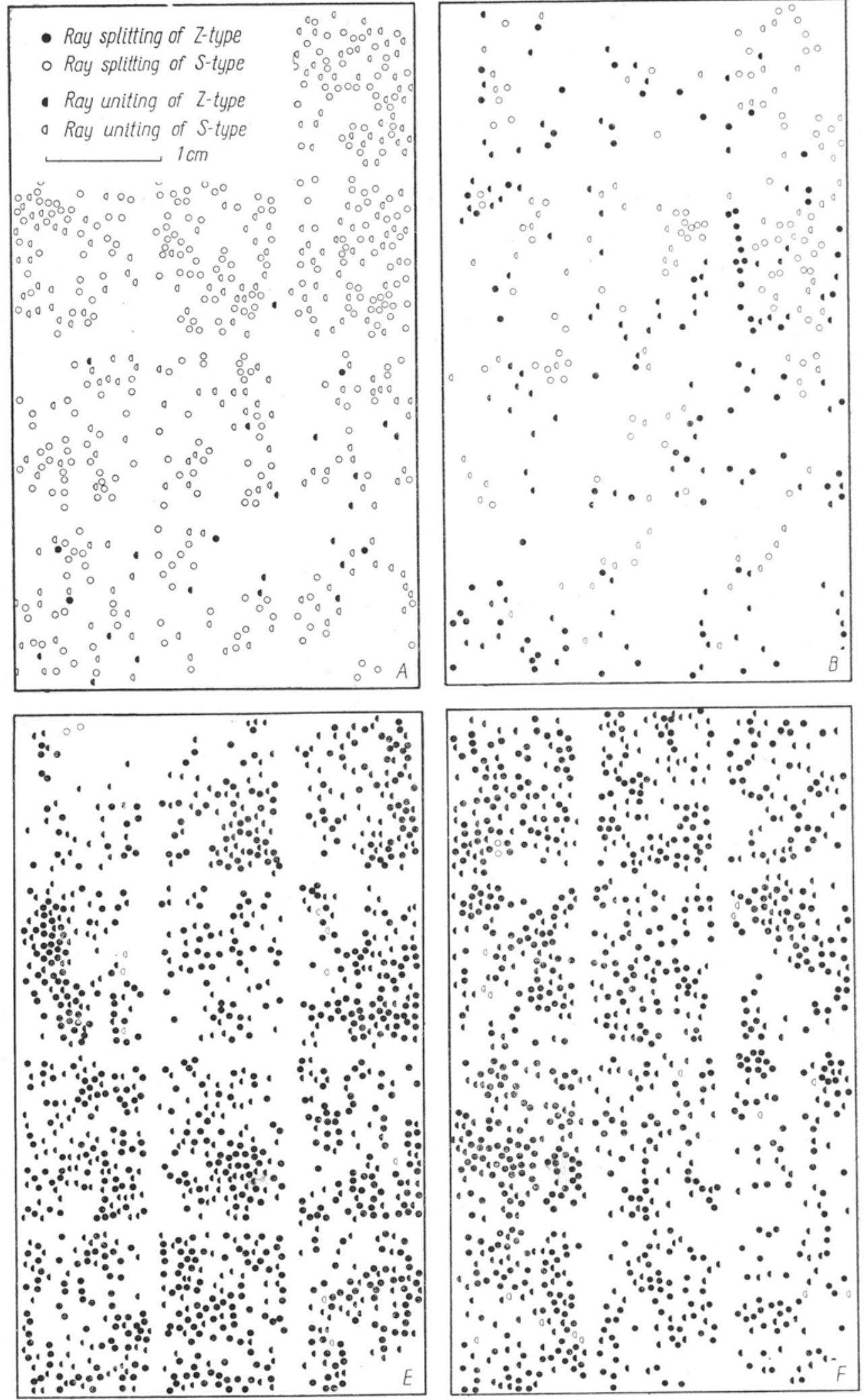

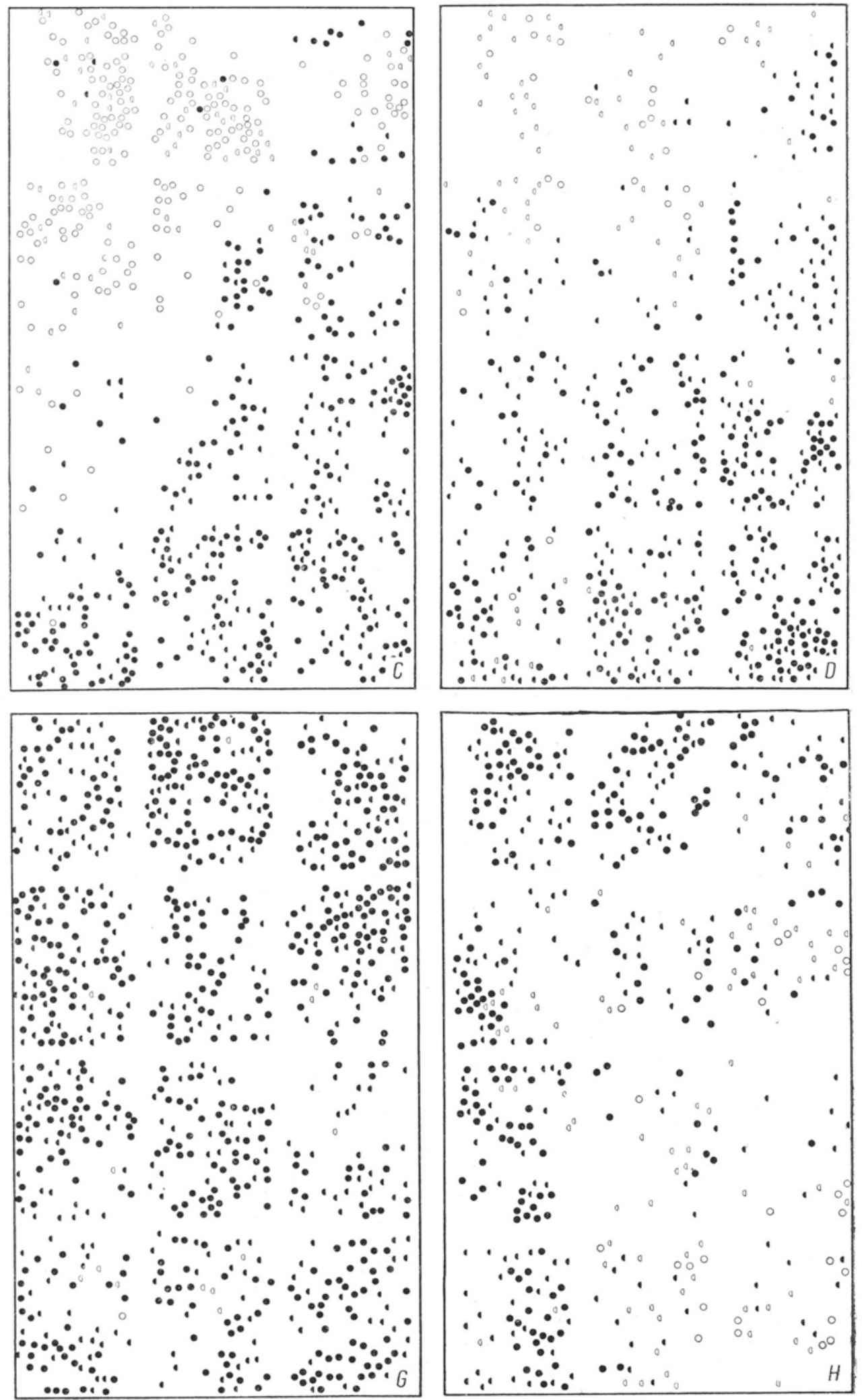

Fig, 5 C, D, G, H 
ray. The case shown in fig. 4 concerns type-S union, that is elimination of the diagonal strand inclined to the right. The adding of some isodiametric cells to the left side of the ray, and elimination of others on the right side are also visible.

In the cambium of coniferous and broadleaved trees there exist domains in which anticlinal partitions, intrusive growth and splitting of rays are uniformly oriented to the right (in $\mathrm{Z}$ - domains) or to the left (in S- domains). A domain pattern appears to occur in the cambium of Platanus also. The domains are marked out by uniformly oriented splittings and unitings of rays. In investigations on the domain pattern of cambium, the largest possible areas of this tissue should be examined. For this purpose block of wood with tangential dimensions $35 \times 60 \mathrm{~mm}$ was divided into 12 small blocks which were cut on microtome and then the rays were photographed on nine, successive TLX. In all the blocks, rays were analysed, and points at which they split or united were plotted on the drawing representing the surface of the block examined. In this way the cambium was mapped in respect to the splitting and uniting of rays occuring during the formation of the annual rings. Maps of the surface on eight successive annual rings are shown in Fig. 5. Circles denote ray splitting, and semicircles ray uniting, the black ones corresponding to Z-type and the empty ones to S-type. Each single splitting or uniting of rays is denoted on the map by a circle or semicircle. As seen, ray splitting in a given direction in a particular locality is always associated with uniting of the rays which are separated by strands inclined in direction opposite to that of splitting. i.e. the both splitting and uniting are of the same type. Uniformity or strong prevalence of one direction of splitting and uniting indicates occurrence of the domains in the cambium of Platanus. Comparison of the maps, each from one terminal leyer of xylem shows, that the pattern of domains in the sycamore changes in time: in Fig. $5 \mathrm{C}$ in the right lower corner the place of the Z-type domain appears, the border of which gradually shifts upward. The opposite border of this domain appears four years later which advances similarly as the preceding one. The lack of data on the orientation of the block in the tree does not allow, unfortunately, to establish whether the domain shifted upwards or donwards in the trunk.

The process of splitting and uniting of rays occurs with a varying initensity. This may be inferred from difference in the density of the marks in Figs 2 and 5. The differences in the frequency and orientation

Fig. 5. Maps showing the directions of splitting and uniting of rays on the same cambium surface in the course of formation of eight successive annual rings. The borders between the domains $Z$ and $S$, which are gradually shifted from lower right side of map upwards are seen. 


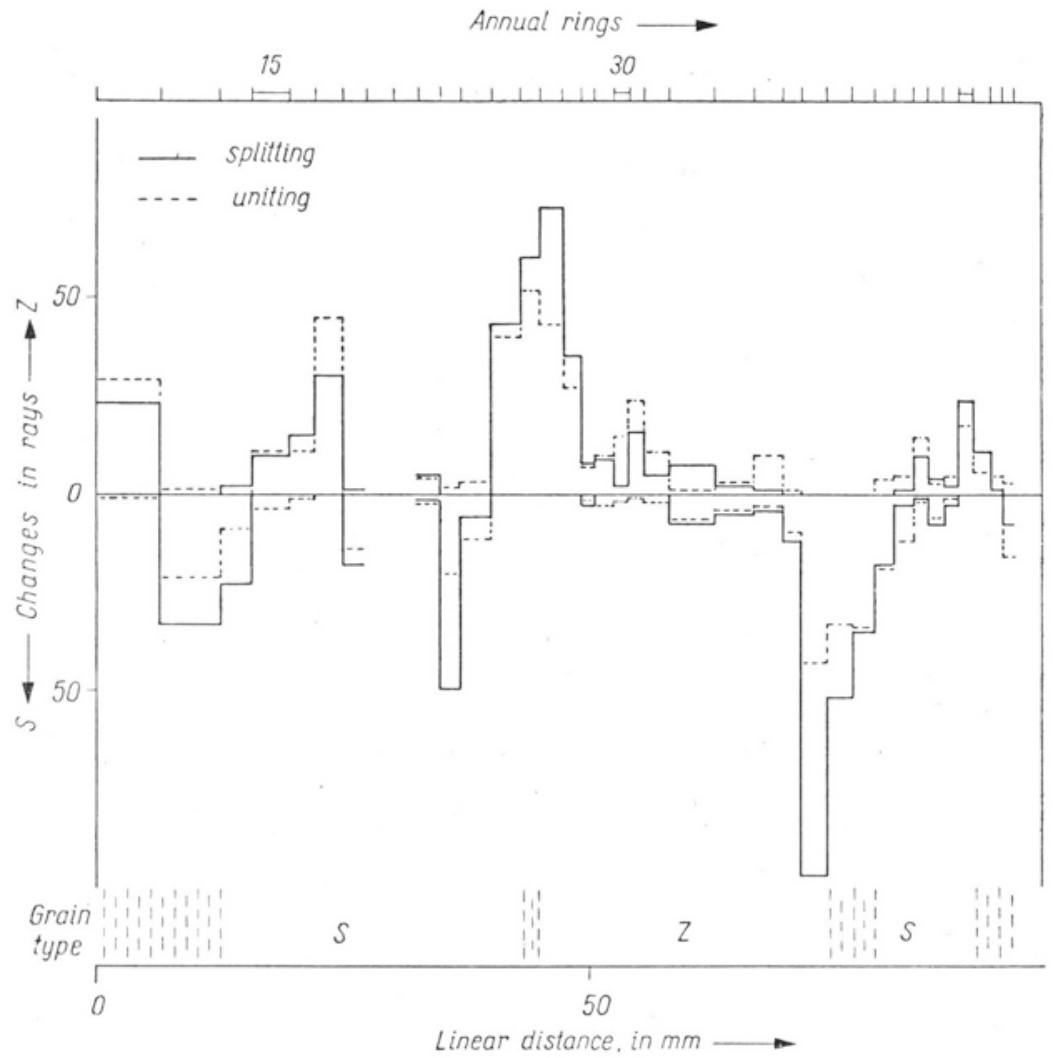

Fig. 6. Number and orientation of splits and unions of rays in the 37-years period of activity of Platanus cambium.

The bars on the graphs above the horizontal line (zero) denote the number of changes of $\mathrm{Z}$ type, and those under the line of $\mathrm{S}$ type. The vertical axis presents the number of splits and unions on à $1.4 \mathrm{sq}$. cm surface in the particular annual rings. Below, the type of grain occuring in the given annual ring is shown. Dashed lines denote annual rings with straight grain

of the changes in the rays are better visible when the splittings and unitings of rays are considered over a many-year activity of the cambium. The differences in the number and orientation of the changes in the rays in the same area of the cambium $(1.4 \mathrm{sq} \mathrm{cm})$ in 37 successive annual rings are shown in Table 1. columns 3 and 4. As seen, a relatively large number of rays undergo changes consisting of splitting and uniting. These changes are oriented to the right - splitting and uniting of Z-type, or to the left - S-type. The frequency of splitting and uniting varies within wide limits, and shows a distinct relation with the thickness of the annual ring. Changes in the rays are generally unidirectional within the annual rings, that is either of $\mathrm{Z}$ or $\mathrm{S}$ type. The orientation of the changes is reversed from $\mathrm{Z}$ to $\mathrm{S}$ and vice versa at irregular time intervals. This is well visible in Fig. 6 in the form of a bar graph. The maximal number of 
Table 1

Frequency of splitting and uniting of rays (number per 100 rays per $1 \mathrm{~mm}$ of xylem). The total ray number studied in one annual ring was about 225

\begin{tabular}{|c|c|c|c|c|c|c|c|c|}
\hline \multirow{2}{*}{$\begin{array}{c}1 \\
\text { Annual ring } \\
\text { no. }\end{array}$} & \multirow{2}{*}{$\begin{array}{c}2 \\
\text { Ring } \\
\text { thickness } \\
(\mathrm{mm})\end{array}$} & \multicolumn{2}{|c|}{$\begin{array}{c}3 \\
\text { No. of split } \\
\text { rays }\end{array}$} & \multicolumn{2}{|c|}{$\begin{array}{c}4 \\
\text { No. of united } \\
\text { rays }\end{array}$} & \multirow{2}{*}{\multicolumn{2}{|c|}{$\begin{array}{l}\quad 5 \\
\text { Frequency } \\
\text { Split. Unit. }\end{array}$}} & \multirow[t]{2}{*}{$\begin{array}{c}6 \\
\text { Grain } \\
\text { type * }\end{array}$} \\
\hline & & & $\mathrm{S}$ & Z & $\mathrm{S}$ & & & \\
\hline 12 & 6,4 & 23 & 0 & 29 & 1 & 1.5 & 2.0 & I \\
\hline 13 & 6,3 & 0 & 33 & 1 & 21 & 2.3 & 1.5 & I \\
\hline 14 & 3,1 & 2 & 23 & 0 & 9 & 3.5 & 1.2 & $\mathrm{~S}$ \\
\hline 15 & 3,9 & 10 & 0 & 11 & 4 & 1.1 & 1.6 & $\mathrm{~S}$ \\
\hline 16 & 2,4 & 15 & 0 & 11 & 1 & 2.7 & 2.2 & $\mathrm{~S}$ \\
\hline 17 & 2,6 & 30 & 0 & 45 & 0 & 5.1 & 7.6 & $\mathrm{~S}$ \\
\hline 18 & 2,5 & 1 & 18 & 0 & 14 & 3.3 & 2.4 & $\mathrm{~S}$ \\
\hline 19 & 2,6 & - & - & - & - & 一 & - & $\mathrm{S}$ \\
\hline 20 & 2,6 & - & - & - & - & - & - & $\mathrm{S}$ \\
\hline 21 & 2,3 & 5 & 2 & 4 & 2 & 1.3 & 1.1 & $\mathrm{~S}$ \\
\hline 22 & 2,1 & 0 & 50 & 2 & 20 & 10.5 & 4.6 & $\mathrm{~S}$ \\
\hline 23 & 3,0 & 0 & 6 & 3 & 11 & 0.8 & 2.0 & $\mathrm{~S}$ \\
\hline 24 & 2,9 & 43 & 0 & 40 & 0 & 5.9 & 6.1 & $\mathrm{~S}$ \\
\hline 25 & 2,1 & 60 & 0 & 52 & 0 & 12.5 & 11.0 & I \\
\hline 26 & 2,5 & 73 & 0 & 43 & 0 & 12.9 & 7,6 & Z \\
\hline 27 & 1,8 & 35 & 0 & 27 & 0 & 8.6 & 6.6 & $Z$ \\
\hline 28 & 1,3 & 8 & 2 & 7 & 2 & 3.3 & 3.4 & $\mathrm{Z}$ \\
\hline 29 & 1,8 & 9 & 0 & 10 & 3 & 2.2 & 3.1 & $\mathrm{Z}$ \\
\hline 30 & 1,6 & 2 & 0 & 15 & 2 & 0.5 & 4.6 & $\mathrm{Z}$ \\
\hline 31 & 1,6 & 16 & 0 & 24 & 1 & 4.4 & 6.9 & $Z$ \\
\hline 32 & 2,5 & 5 & 0 & 11 & 2 & 0.8 & 2.2 & $Z$ \\
\hline 33 & 4,6 & 8 & 7 & 1 & 7 & 1.4 & 0.7 & Z \\
\hline 34 & 4,0 & 2 & 5 & 3 & 4 & 0.7 & 0.7 & $Z$ \\
\hline 35 & 3,1 & 1 & 4 & 10 & 3 & 0.7 & 1.8 & $Z$ \\
\hline 36 & 1,7 & 0 & 12 & 1 & 10 & 3.1 & 2.8 & $\mathrm{Z}$ \\
\hline 37 & 2,5 & 0 & 97 & 0 & 43 & 17.2 & 7.6 & $\mathrm{Z}$ \\
\hline 38 & 2,6 & 0 & 52 & 0 & 33 & 8.8 & 5.6 & 1 \\
\hline 39 & 2,2 & 0 & 35 & 0 & 34 & 7.0 & 6.8 & 1 \\
\hline 40 & 2,1 & 0 & 18 & 4 & 19 & 3.8 & 4.8 & $\mathrm{~S}$ \\
\hline 41 & 1.8 & 1 & 3 & 5 & 12 & 0.9 & 4.1 & $\mathrm{~S}$ \\
\hline 42 & 1.5 & 10 & 1 & 14 & 2 & 3.2 & 4.7 & $\mathrm{~S}$ \\
\hline 43 & 1.7 & 4 & 8 & 3 & 6 & 3.1 & 2.3 & $\mathrm{~S}$ \\
\hline 44 & 1.4 & 2 & 3 & 5 & 1 & 1.5 & 1.8 & $\mathrm{~S}$ \\
\hline 45 & 1.5 & 24 & 0 & 18 & 0 & 7.0 & 5.3 & $\mathrm{~S}$ \\
\hline 46 & 1.5 & 11 & 0 & 6 & 0 & 3.2 & 1.7 & I \\
\hline 47 & 1.5 & 1 & 0 & 5 & 0 & 0.2 & 1.4 & I \\
\hline \multirow[t]{2}{*}{48} & 1.2 & 0 & 8 & 3 & 16 & 2,9 & 7.0 & \multirow[t]{2}{*}{1} \\
\hline & Total & 401 & 387 & 413 & 283 & n 4.2 & 3.9 & \\
\hline
\end{tabular}

* type of grain: | - straight grain, $\mathrm{S}$ - inclined to left, $\mathrm{Z}$ - inclined to right 


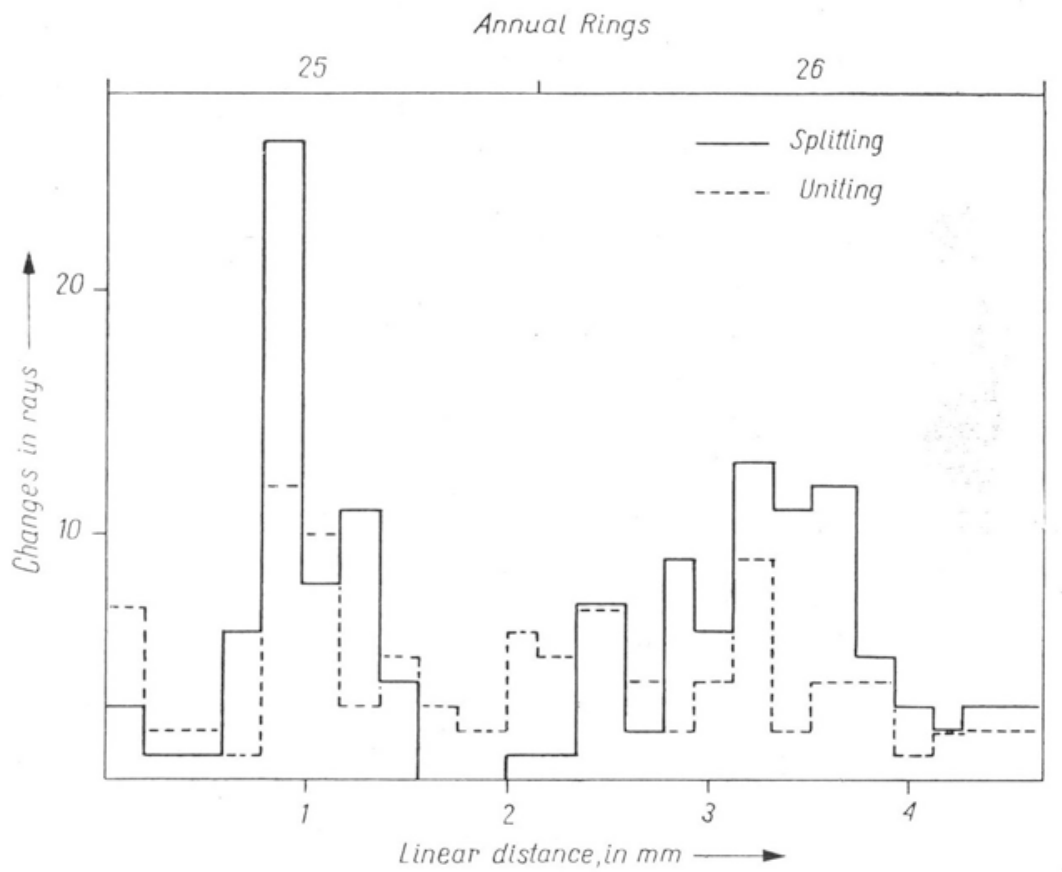

Fig. 7. Number of ray splits and unions in successive layers in to which two annual rings were divided. Vertical axis shows number of splits, respectively unions of rays on a $1.4 \mathrm{sq}$. cm cambium surface in the course of formation of xylem layer of thickness equal to the width of the block.

changes in the rays falls to the period when a change occurs between the two alternative types of grain.

The frequency of the changes in the rays, that is the number of splittings or unitings per 100 rays in the period of formation of a $1-\mathrm{mm}$ xylem layer is shown in Table 1, column 5 . The frequency of these changes varies from 0.2 to 17.2 as regards splitting and from 0.7 to 11.0 as regards uniting of rays. The former is higher in the rays in periods when the grain type undergoes change (maximal frequency of changes), that is in the annual rings no. 22, 26, 37. The situation seems to be reversed in the rings in which the type of grain is continued (low frequency of changes). This might be an indication that, when the type of grain has to be changed, the splitting of rays associated with the formation of strands of the longitudinal system inclined in the new direction preceds the loss of strands inclined in the primary direction.

In view of the continuous increase in the stem circumference there is a need for new rays, because the number of rays falling to one unit of tangential cambium surface should be constant ( $\mathrm{r}$ a u n, 1955). The mean rate of ray splitting in the period of 37 years of activity of the sycamore cambium was higher by 7.2 percent than mean rate of uniting. 
This difference probably resulted from the need for new rays as the trunk thickened.

Attempts were also undertaken to establish in which part of the annual ring does ray splitting and uniting occur most intensively. For this purpose successive wood sections separated by a distance of $160 \mu$, from the rings nos 25 and 26 , in which changes in the rays were very intensive, were compared. The results (Fig. 7) indicate that the changes were most intensive at the middle of the annual ring.

The appearance and relative position of the rays in Platanus depend on their splitting and uniting. The behaviour of a group of the same rays in the course of repeated changes of the direction of inclination of the grain in sycamore wood is shown in Fig. 8. (Data from the same series as in Table 1). The number denotes the TLX layer no. The vertical lines between the drawings are parallel to the long axis of the block and, probably, to the long axis of the tree trunk. The unshaded rays represent those which were close to the group examined and joined it. All the rays are arranged parallelly to one another and in the direction of grain inclination. It appears that during the change in grain inclination $(21-26)$, the rays rotate around their own centres. This process leads at first to an approximation of the tips of neighbouring rays and then to their unitting into larger rays $(27-29)$. With further inclinaltion of the grain the newly formed large rays may split to smaller ones which undergo further roltation. Sometimes uniting of two rays and their splitting in opposite direction occurs at the same spot. In this case splitting occurs usually earlier than uniting, and small triangular rays are formed which unite with large rays $(27-30)$ or move further away from them as the xylem is produced (37-47). It is interesting that the centres of the rays in the Fig. 8 continuously follow one straight line inclined to the right, independenitly of the number and orienitaltion of the changes in the rays and of the direction of grain inclination. This indicates that the centres of the rotating rays occupy a constant position in relaltion to one another and to the stem axis.

The changes in the rays here presented are due to the developmental processes of the cambial fusiform initials. They were observed in the

Fig. 8. Developmental changes and ray rotation in the course of inclination of Platanus grain. The successive TLX layers numbered centrifugally. $Z$ and $S$ in circles denote ray splitting to the right and the left respectively " $Z$ and $S$ " alone - ray uniting of right and left type. The vertical axis of every drawing is parallel to the long axis of wood block. It is seen that the centres of the rotating rays remain in the same position in relation to one another and to the block axis. The uniform orienitation of changes the splits and unions visible. Distance between TLX nos. 21 and $47-59 \mathrm{~mm}$. 


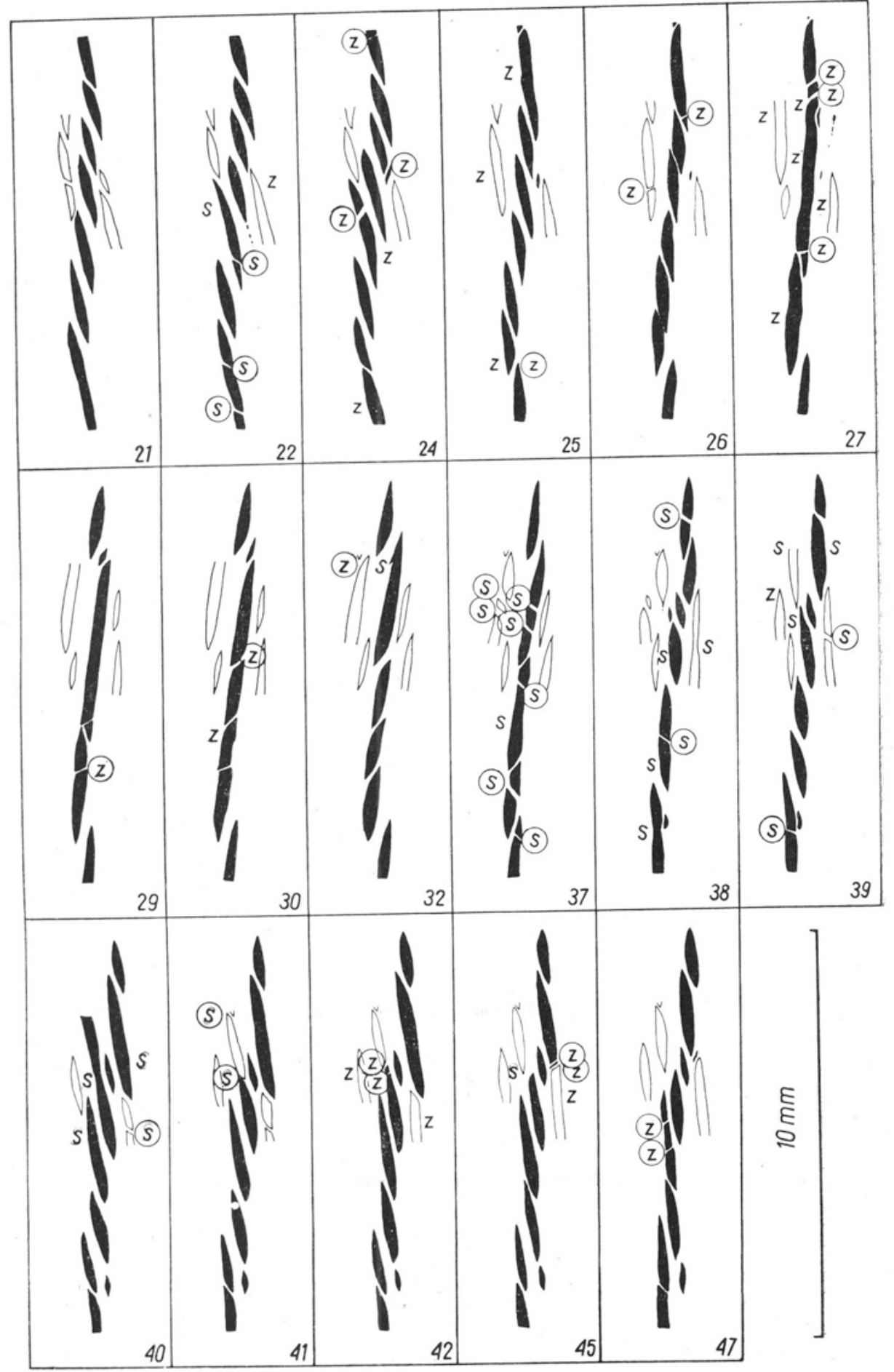

Fig. 8 
successive TLX layers in which the xylem cells pattern is the same as in the cambium at the moment of formation of these layers. It was attempted to analyse the developmental processes in the fusiform initials directly in active cambium of Platanus acerifolia. A large accumulation of new partitions from anticlinal division was found. The partitions were uniformly inclined to the right.(Z) in some cambium samples, or to the left (S) in others. A fragment of adtive cambium with several newly formed partitions inclined to the left (S) is shown in fig. 9 (A). The end of a fusiform initial is also seen after in trusive growth in the direction of the partition inclination (B). The question arises whether the observed inclined position of the partitions is the result of oblique anticlinal division or of intrusive growth of the tips formed in transverse division. The author succeeded in finding several mitotic figurs from anticlinal division. Fig. $9 C-E$. The case shown in Fig. $9 F$ indicates cell plate curved so as to produce a conforming partition (S type).

\section{DISCUSSION}

The changes in the cell paittern of wood with interlocked grain was investigated in order to establish what developmental processes in the cambium lie at the base of the changes in the orientation of the grain in this type of wood. Advantage was taken in these stuldies of the fact that in broadleaved trees the palttern of the cambium cells is preserved in the TLX layers (H e jnow ic z and Kraw c z y s z n , 1969).

Vascular cambium may undergo reconstruction during development, that means that the pattern of its rays and fusiform initials may change. In the sycamore this reconstruction is particularly intensive in connection with the formation of interlocked grain. Precise study of the changes in the fusiform initials is not possible on account of the difficulties with their identification on the successive TLX layers, but the changes of rays can be analysed.

The sycamore rays undergo intensive splitting and uniting. Splitting occurs like in other broadleaved trees: Pyrus (Evert, 1961), Liriodendron (Che adle and Esla u, 1964), Aesculus, Acer (He jnowicz and Krawczyszyn, 1969). This process concerns undoubtedly the initial layer of the cambium. It appears that in the sycamore it starts in the xylem mother cells. In the earliest period of ray splitting in this tree, at the site of the future ,fissure”, tips of fusiform cells may be found intruding into the ray from the neighbouring strands of the longitudinal system. However, on the next tangential sections, isodiametric cells of the given radial file may be found again at the site where the tips of the fusiform cells previously were, and on further sections the final separaltion of the ray into two parts ultimately occurs. The fact that after 


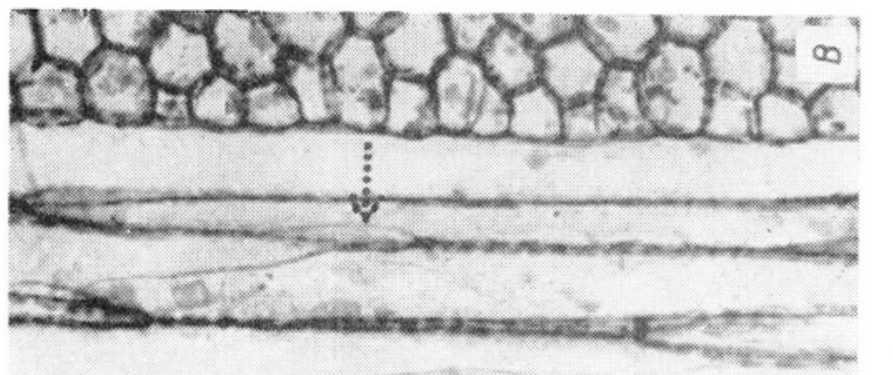

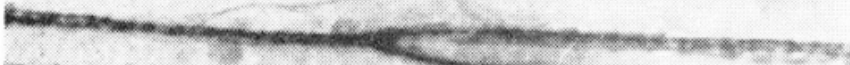

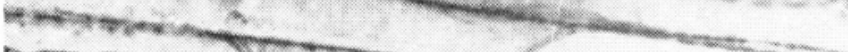

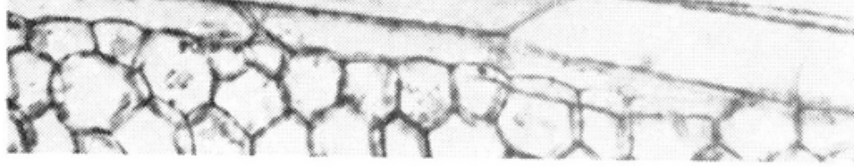

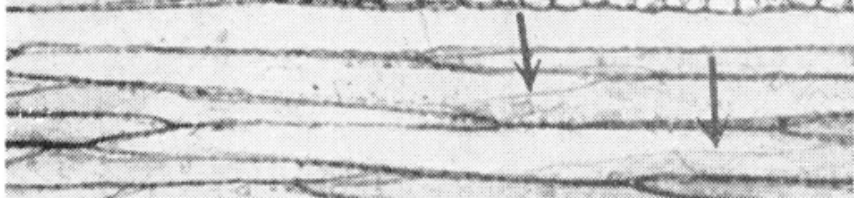

C.

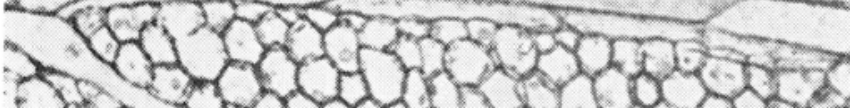

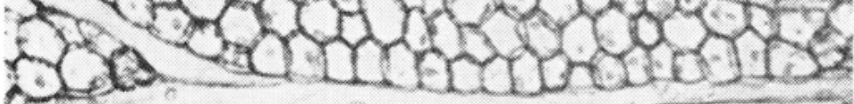

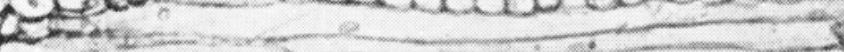

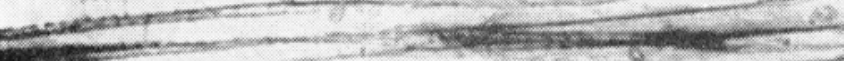
Q.2.

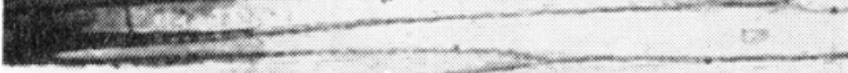

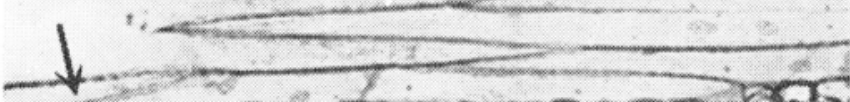

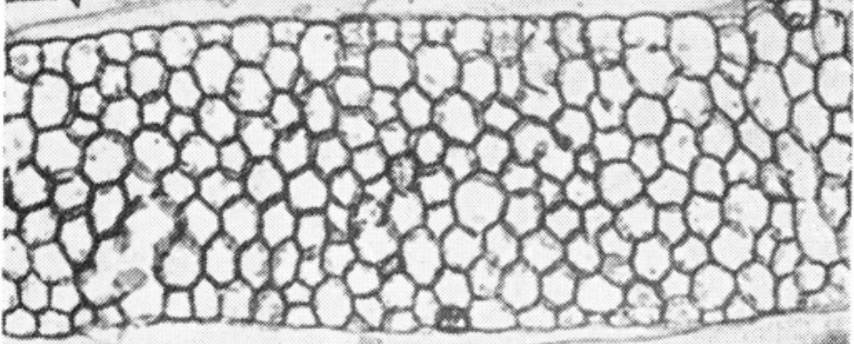

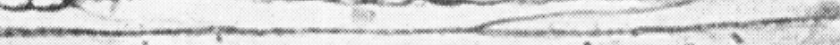

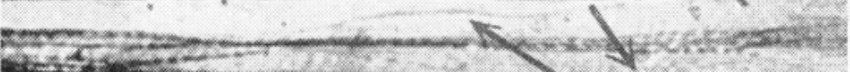
atint 

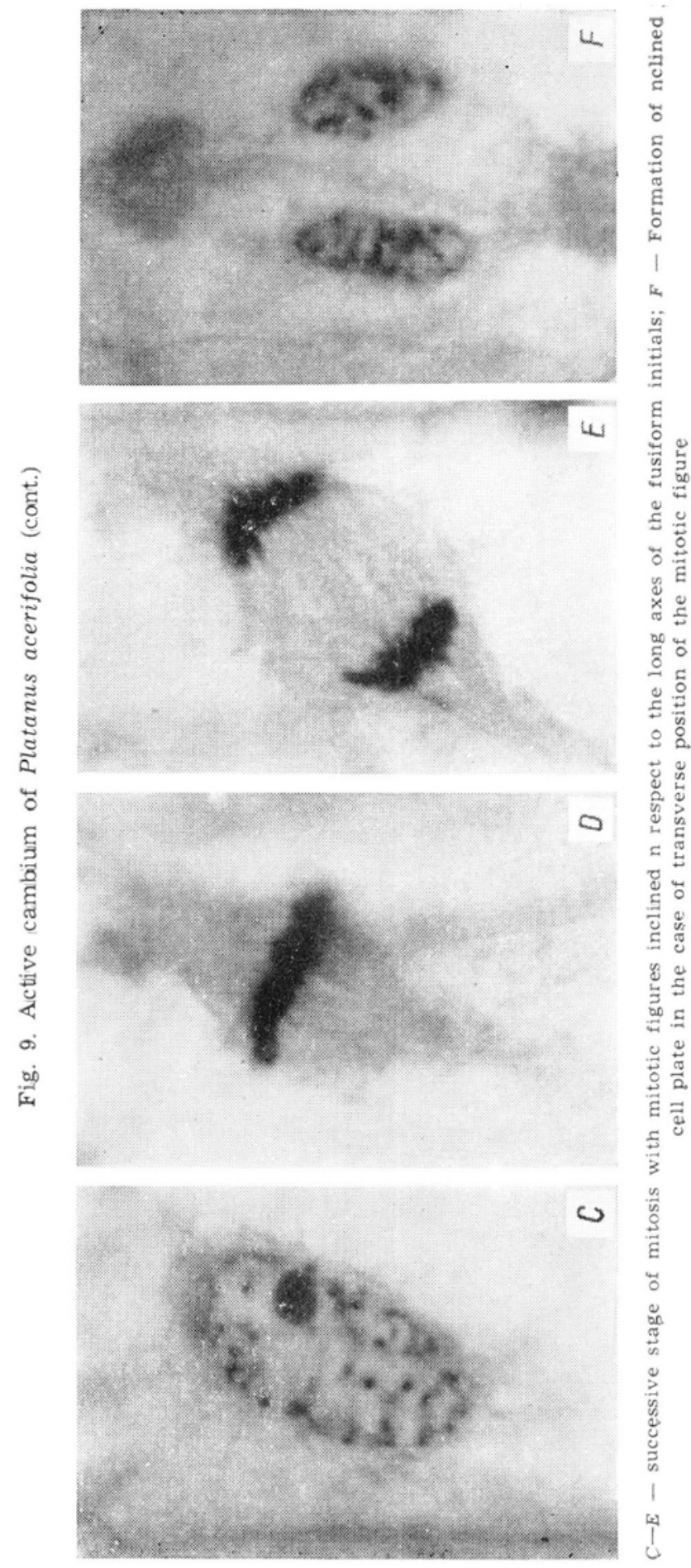
a certain time splitting of the ray occurs at the site previously occupied alternately by fusiform and ray cells indicates that the process of intrusion of the fusiform cells passes to the zone of the initial cambium layer. The young fibres intruding into the ray make the growth of the cells formed by division of the ray initials remaining in the cambium difficult, and oblige them to grow in tangential direction. This explains why some ray cells are 2-4 times larger than the remaining ones on the tangential section. These large cells may misleadingly suggest that ray splitting in Platanus occurs by transformation of ray initials to fusiform initials. The latter way of ray spliting has been found in primitive dicotyledons in which the rays are but little specialised ( $\mathrm{C}$ h a t t a w ay, 1933; B arghoor n, 1940, 1941).

Ray splitting in here studied tree species is unidirectional, and this may be considered as the result of oriented intrusive growth of fusiform cells. The figures in the above mentioned papers seem to indicate that splitting is unidirectional also in those species in which it occurs as the result of transformation of ray initials to fusiform initials.

In some dicotyledonous plants with heterogeneous rays, ithe uniting of rays may occur by vertical elongation of the marginal initials and their derivatives (B a r g hoor n, 1940). Ray uniting in the sycamore occurs by the loss of intervening initials and their partial transformation to ray initials similarly as it happens in Pyrus (E v e r it, 1961) and Liriodendron (Cheadle and Esa u, 1964). Uniting of rays in the studied species involves sometimes 20 percent of the rays. This process is oriented loss of the multicellular strands of the longitudinal system inclined in the direction from which the cambium at the given moment withdraws, occurs.

It should be stressed that the directions of ray uniting and splitting are the same on large areas of the cambium: the intrusive growth of fusiform initials to the right $\mathrm{Z}$ (left $\mathrm{S}$ ) is associated with the loss of initials in the strands inclined in the opposite direction - left (righit).

It is known that tree cambium shows a pattern of domains. The present investigations indicate that ray uniting is also uniformly oriented in a domain, it consists, namely, in loss of strands of fusiform initials inclined in reverse direction to that prevailing within the domain in respect to anticlinal division and intrusive growth. It would seem therefore, that domains may be delimited by analysing either the orientation of the partitions in anticlinal division, more convenient in conifers, or the orientation of splitting and uniting of rays in broadleaved trees. In the sycamore it is not possible by analysis of the TLX series to determine the unidirectional anticlinal divisions. In this connection critics may doubt whether unidirectional anticlinal divisions occur in the domains. Therefore the direction of anticlinal divisions were investigated in active cambium. Not very many divisions were studied, but those observed were 
unidirectional. The correlation between the direction of anticlinal divisions and intrusion growth in Aesculus (cf. He jnowicz and $\mathrm{Kraw}-$ c z y s z y n, 1969) seems to be sufficient evidence that in the domain of the sycamore, delineated on basis of intrusive growith and loss of fusiform initials, anticlinal divisions are uniformly oriented. The occurrence on the same cambium area of alternating $\mathrm{Z}$ and $\mathrm{S}$ domains must have a decisive influence on grain orientation in the wood produced, i.e. the grain must oscilate from right to left and so on, as it is characteristic for interlocked grain. It would result from the definition of interlocked grain (B r o w $\mathrm{n}$ et al., 1949; K a d a mbi, 1951; Limaye, 1954) that there occurs on the entire trunk surface a uniform spiral, that is at any point of this surface there exists only one type of grain inclined to the right or left. The present studies seem to indicate that the wood of Platanus does not fit this definition. On the surface of its annual rings there existed simultaneously areas of grain inclined to the right, to the left, and areas of straight grain. To the borders between the different types of grain corresponded the lborders between domains $\mathrm{Z}$ ans $\mathrm{S}$.

The changes in the Platanus rays are conditioned by changes of the fusiform initials. Thus, the frequency of ray splitting is directly dependent on the frequency of anticlinal divisions and the rate of intrusive growth of the fusiform initials, and the frequency of ray union is related to the intensity of fusiform initials elimination. In conifers the frequency of anticlinal division depends on the age of the cambium and the rate of xylem deposition (B a n $n$ a $n, 1950,1967)$. In the latter case this frequency is higher in the narrow rings and lower in the wider ones. In Pyrus the frequency of anticlinal division alternates similarly as fruit bearing (Evert, 1961). In the sycamore the rate of xylem deposition does not seem to affect the frequency of changes in the rays.

The number of rays is known to increase with continuous increase of the trunk circumference. In Platanus this occurs by way of splitting of the alredy existing rays. This is indicated by the 7.2 percent increase in the frequency of splitting as compared to that of uniting. B a n nan (1950), Braun (1955), Evert (1961) and Cheadle and Esau (1964) attribute to the formation of new rays, by partial or complete fragmentation of the fusiform initials, the increase in the number of rays. The newly formed rays are then always uniseriate. But, in the bole of a mature sycamore specimen uniseriate rays occur very seldom, and usually by cutting off the ray initials belonging to the edges of the multiseriate rays, and not by fusiform initials division. (The formation of new rays by way of division of fusiform initials may be seen in young branches of the sycamore). The present data agree with the view of Barghoor $n$ (1941) that in species exhibiting no uniseriate rays, the requirement for this tissue is fulfilled by the splitting of the alredy existing multiseriate rays. 


\section{SUMMARY AND CONCLUSIONS}

1. In the successive layers of terminal xylem in wood of Platanus with interlocked grain, intensive splitting and uniting of rays was observed. Splitting occurs by intrusion into the ray of fusiform cells. There is reason to believe that this process starts in the zone of xylem mother cells. Uniting of rays results from the loss of fusiform initials in the strand separating the rays.

2. Splitting and uniting of rays is unidirectional on the large area (domain) of the cambium. Domains may be of $\mathrm{Z}$ and $\mathrm{S}$ type. In domain $\mathrm{Z}$, ray splitting occurs to the right and uniting of the rays separated by strands of the longitudinal system inclined to the left. In domain $\mathrm{S}$ these processes occur in opposite directions.

3. In the 37-year period of cambium activity the orientation of the changes in the rays was reversed at irregular time intervals. The occurrence of alternating $\mathrm{Z}$ and $\mathrm{S}$ domains on the same area of cambium seems to bring about the alternation of the grain inclination from right to left and back again in wood with interlocked grain exhibited by Platanus.

4. The frequency of changes in the rays, that is the number of splittings and unions falling to 100 rays in the period of deposition of xylem layer $1 \mathrm{~mm}$ thick varies within wide limits for ray splitting $(0.2-17.2)$ and for ray uniting $(0.7-11.0)$. The increase in the number of ray splittings and unions occurred abruptly, and the decrease gradually. The maximal number of changes in the rays fell to the periods in which the grain withdrew from the previous direction of inclination. The frequency of splittings is by 7,2 percent higher than that of unitings. Owing to this the number of rays rises with the thickening of the bole.

5. In active cambium of the sycamore the formation of new uniformly inclined partitions from pseudotransverse divisions was noted. The anticlinal divisions are inclined from the very beginning since the mitotic figures are slantingly arranged.

The author wishes to thank to dr Z. Hejnowicz for his aid, valuable advice and critical comments in the course of this work.

This investigation was supported in part by a grant of the United States Department of Agriculture under the P.L. 480.

\section{REFERENCES}

Bannan M. W., 1950, The frequency of anticlinal divisions in fusiform cambial cells of Chamaecyparis, Amer. J. Bot. 37: 511-519.

Bannan M. W., 1964, Tracheid size and anticlinal divisions in the cambium of Pseudotsuga, Can. J. Bot. 12: 603-631.

B a n n a n M. W., 1966, Spiral grain and anticlinal divisions in the cambium of conifers, Can. J. Bot. 44: 1515-1538.

Bannan M. W., 1967, Sequential changes in rate of anticlinal division, cambial cell length, and ring width in the growth of coniferous trees, Can. J. Bot. 45: 1359-1369.

Barghoorn E. S., Jr, 1940, The ontogenetic development and phylogenetic specialization of rays in the xylem of dicotyledons. I. The primitive ray structure, Amer. J. Bot. 27: 918-928.

B a r g h o or n E. S., Jr, 1941, The ontogenetic development and phylogenetic specialization of rays in the xylem of dicotyledons. II. Modification of the multiseriate and uniseriate rays, Amer. J. Bot. 28: 273-282. 
Bra un H. J., 1955, Beiträge zur Entwicklungsgeschichte der Markstrahlen, Botan. Studien No. 4: 73-131.

B r o w n H. P., A. J. Panshin and C. C. Forsaith, 1949, Textbook of wood technology, Vol. I. McGraw-Hill Book Company, Inc. New York.

$\mathrm{C}$ h a t t a w a y M. M., 1933, Ray development in the Sterculiaceae, Forestry 7: 93-108.

$\mathrm{C}$ h e a dle V. I. and K. Es a u, 1964, Secondary phloem of Liriodendron tulipifera, Univ. Calif. Publ. Bot. 36: 143-252.

Evert R. F., 1961, Some aspects of cambial development in Pyrus communis, Amer. J. Bot. 48: 479-488.

H a rris I. M., 1969, On the causes of spiral grain in corewood of Radiata pine, N. Z. J. Bot. 7: 189-213.

Hejnowicz Z., 1961, Anticlinal division, intrusive growth, and loss of fusiform initials in nonstoried cambium, Acta Soc. Bot. Pol. 30: 729-748.

Hejnowicz Z., 1964, Orientation of partition in pseudotransverse division in cambia of some conifers, Can. J. Bot. 42: 1685-1691.

Hejnowicz Z., 1968, The structural mechanism involved in the changes of grain in timber, Acta Soc. Bot. Pol. 37: 347-365.

Hejnowicz Z. and J. Krawczyszyn, 1969, Oriented morphogenetic phenomena in cambium of broadleaved trees, Acta Soc. Bot. Pol. 38: 547-560.

J o n e s B. E., 1963, Cell adjustments accompanying the development of spiral grain in a specimen of Pseudotsuga taxifolia, Brit. Commonwealth Forestry Rev. 42: $151-158$.

$\mathrm{K}$ a d a m bi K., 1951, On the nature of twisted fibre and the occurrence of interlocked fibre in some trees, VIII Silvicult. Confer., Dehra Dun India, 227-228.

L i m a y V. D., 1954, Interlocking of grain in Indian timbers, Indian Forester. 80: $6-9$.

N e e f F., 1914, Utber Zellumlangerung: Ein Beitrag zur experimentellen Anatomie, Zt. Botan. 6: 465-547.

N e w m a n I. V., 1955, Miscellaneous notes on inclination of grain in Pinus radiata D. Don. and Pinus sp., Project W. S. 17, Laboratory Report No. 1, Forest Products Laboratory C.S.I.R.O. Melbourne, pp. 16.

Srivastava L. M. and T. P. O'Brien, 1966, On the ultrastructure of cambium and its vascular derivatives. I. Cambium of Pinus strobus L. Protoplasma 61: 257-276 .

\section{Jednokierunkowe rozszczepianie i laczenie promieni w kambium Platanus.}

\section{Streszczenie}

1. Porównując warstwy drewna $\mathrm{z}$ kolejnych granic między słojami rocznymi u platana obserwowano intensywne rozszczepianie i łączenie promieni. Rozszczepianie zachodzi przez wrastanie w promień komórek wrzecionowatych. Istnieją podstawy do przypuszczenia, że proces ten zostaje zapoczątkowany w strefie różnicowania drewna. Łączenie promieni polega na eliminowaniu komórek wrzecionowatych znajdujących się w paśmie między promieniami.

2. Rozszczepianie i łączenie promieni jest jednokierunkowe na dużym obszarze kambium czyli domenie. Występują domeny typu Z i typu S. w pierwszych zachodzi rozszczepianie promieni $\mathrm{w}$ kierunku na prawo i łączenie promieni rozdzielonych pasmami systemu podłużnego nachylonymi na lewo. W domenie S procesy te zachodzą w kierunku przeciwnym. To oznacza, że wzrostowi intruzywnemu komórek wrzecionowatych w kierunku na prawo $\mathrm{Z}$ (na lewo) towarzyszą eliminacje komórek w pasmach nachylonych w kierunku przeciwnym tj. odpowiednio na lewo (na prawo). 
3. W okresie 37 letniej działalności kambium kierunek zmian promieni ulegał odwracaniu na przeciwny w nieregularnych odstępach czasu. Obecność naprzemian domen $\mathrm{Z}$ i S na tym samym obszarze kambium wydaje się decydować o oscylacji kierunku włókna $\mathrm{z}$ prawa na lewo w drewnie o przeplatanym włóknie - ,interlocked grain" - jakim charakteryzuje się drewno Platanus.

4. Częstatliwość zmian promieni, tj. ilość rozszczepień lub łączeń przypadających na 100 promieni w okresie odkładania warstwy drewna o grubości $1 \mathrm{~mm}$, wacha się $\mathrm{w}$ szerokich granicach od 0,2 do $17,2 \mathrm{~W}$ przypadku rozszczepiania promieni i od 0,7 do $11,0 \mathrm{w}$ przypadku łączenia. Wzrost ilości rozszczepień i łączeń promieni odbywał się gwałtownie a spadek - łagodnie. Maksymalna ilość zmian promieni przypadała na okresy w których następowało wycofywanie się włókna z poprzedniego kierunku nachylenia. Występuje tu $7,2^{\%} \%$ nadwyżka częstotliwości rozszczepień w stosunku do łączeń promieni. Dzięki temu zwiększa się ilość promieni przy grubieniu pnia.

5. W kambium aktywnym platana stwierdzono występowanie nowych ścian z podziałów antyklinalnych nachylonych jednolicie. Podziały antyklinalne są tu od razu ukośne dzięki ukośnemu ułożeniu figur mitotycznych.

Zakład Anatomii i Cytologii Roślin

Instytutu Botaniki i Biochemii U. Wr. Wrocław, Kanonia 6/8

(Wpłynęło: dn. 9.05.1970 r.) 